$\begin{array}{ll}\text { Variants } & \begin{array}{l}\text { Variants } \\ \text { The Journal of the European Society for Textual } \\ \text { Scholarship }\end{array}\end{array}$

15-16 | 2021

Textual Scholarship in the Twenty-First Century

\title{
Creators' Intentions and the Realities of Performance: Some Exemplary Editorial Problems from the Savoy Operas
}

\section{Ronald Broude}

\section{(2) OpenEdition \\ 12 Journals}

\section{Electronic version}

URL: https://journals.openedition.org/variants/1305

DOI: 10.4000/variants. 1305

ISSN: 1879-6095

\section{Publisher}

European Society for Textual Scholarship

\section{Printed version}

Date of publication: 1 July 2021

Number of pages: $63-80$

ISSN: 1573-3084

\section{Electronic reference}

Ronald Broude, "Creators' Intentions and the Realities of Performance: Some Exemplary Editorial

Problems from the Savoy Operas", Variants [Online], 15-16 | 2021, Online since 01 July 2021,

connection on 16 July 2021. URL: http://journals.openedition.org/variants/1305 ; DOI: https://doi.org/ $10.4000 /$ variants. 1305 


\title{
Creators' Intentions and the Realities of Performance: Some Exemplary Editorial Problems from the Savoy Operas
}

Ronald Broude

\begin{abstract}
When playwrights, composers and choreographers bring scripts, scores, and choreographies to first rehearsals, these are provisional documents that still need to be tested, transformed into audible sounds and visible movements. Works that are successful enough to be revived go through similar processes of testing and adjustment for each new production. In no genre are such adjustments so many or so far reaching as in opera. The Savoy Operas the collaborations of Gilbert and Sullivan - constitute an excellent repertoire in which to study the dynamics of this process, for their genesis and performing history can be traced in a wealth of documentation. Although performances were controlled for three quarters of a century by the D'Oyly Carte Opera Company, a troupe committed to performing these works exactly as their creators had intended, numerous adjustments were made over the years. Because few good performers will regard any text as altogether binding, editors should supplement their clear texts with enough information, provided in critical commentary and appendices, to enable performers to exercise intelligently the freedom they will almost certainly claim.
\end{abstract}

THE SCRIPTS, SCORES, AND CHOREOGRAPHIES that playwrights, composers and choreographers bring with them to first rehearsals are necessarily provisional documents. * Those documents represent the creators' original intentions, but only when those intentions have been tested in rehearsal, transformed into audible sounds and visible movements, can creators know if their conceptions are effective onstage ${ }^{1}$ Invariably, adjustments must be made to meet the realities of performance with specific performers, specific venues and specific audiences, and the creators' pre-rehearsal intentions are modified accordingly. The process

* Editors' Note: The editors of this issue have exercised their editorial prerogative to redact all racial slurs from this essay. This includes those cases where they were quoted verbatim from the original source text (see page 73 below). These changes have been made with the author's consent. For a more detailed justification of how and why these redactions took place, please refer to our editorial preface in the current issue (esp. pages viiitx.

For a perceptive discussion of the transformations undergone by a playwright's script during rehearsals, see Philip Gaskell's study of the textual changes in Tom Stoppard's Travesties (Gaskell 1978 245-62). 
often extends beyond rehearsals to the days or weeks following opening night; when all adjustments have been made, the work is said to have been "settled" or "frozen". If a work is successful enough to merit successive productions, the revivals undergo a similar process of revision. Creators sometimes oversee revivals of their works, but often revivals take place without them, either because they are otherwise occupied or because they are dead. In the absence of a work's creator, new adjustments are made by those involved in the new production. Sometimes, such adjustments become firmly fixed elements of performing traditions, so that even knowledgeable audiences are unable to distinguish them from what was present in the original production.

These aspects of performing works raise for editors a variety of problems not usually present with works meant to be read by their audiences directly off the page, works such as novels, poems and essays ${ }^{2}$ The Savoy Operas ${ }^{3}$ the collaborations of librettist W. S. Gilbert and composer Arthur Sullivan provide an unusual opportunity to study the dynamics of performing works over a substantial span of time. They were performed at first under the direction of the creators themselves and later, after the creators' deaths, under the control of a single organization - the D'Oyly Carte Opera Company — committed to performing the works exactly as their creators had intended 4 The D'Oyly Carte Opera Company was formed by Gilbert, Sullivan and Richard D'Oyly Carte, the impresario who had brought librettist and composer together and whose diplomatic skills had kept them so, notwithstanding differences in personality and artistic aims. The thirteen works for which both music and libretto survive were composed between 1873 and 1896, and until 1960, when international copyright in them expired, they were maintained in repertory by the D'Oyly

2 For a discussion of differences between "page texts" (texts meant to be experienced by audiences reading them directly off the page) and "stage texts" (those of performing works, the texts of which audiences need never see), see Broude 2011. passim, but esp. pages $24-25$.

3 'Savoy Operas' is the collective name given to the thirteen collaborations of librettist W. S. Gilbert (1836-1911) and composer Arthur Sullivan (1852-1900) for which both music and libretto survive. The thirteen are Trial by Jury (1875), The Sorcerer (1877), H. M. S. Pinafore (1878), The Pirates of Penzance (1879), Patience (1881), Iolanthe (1882), Princess Ida (1884), The Mikado (1885), Ruddigore (1887), The Yeomen of the Guard (1888), The Gondoliers (1889), Utopia, Ltd. (1893), and The Grand Duke (1896). The operas take their name from the Savoy Theatre, expressly built in 1882 by Richard D'Oyly Carte to house productions of Gilbert and Sullivan's operas, which by that time had become an institution. All the operas that opened before 1882 had their premieres at other theatres, although all thirteen were at some time performed at the Savoy. A fourteenth work, Gilbert and Sullivan's first collaboration, Thespis (1871), survives only in part: the libretto was printed and so reaches us in its entirety, but only snatches of the music have been preserved: "Climbing over Rocky Mountain" was later recycled in Pirates (1:5). Since Sullivan was frugal with what he composed, it seems likely that other music from Thespis may have been recycled. On Thespis, see Rees 1964

4 For a history of the D'Oyly Carte Opera Company, see Joseph 1994 The casts of 86 years of D'Oyly Carte productions are catalogued in Rollins and Witts 1962 For a recent memoir of the last years of the Company, see Mackie 2018 
Carte Opera Company, which tightly controlled both its own productions and productions by other organizations to which it rented, under strict licenses, the performing materials needed to stage full-scale productions. The D'Oyly Carte Opera Company was founded in 1879, when London had two competing productions of H. M. S. Pinafore, Gilbert and Sullivan's fourth collaboration and first real hit; both then and later (when pirates in America were mounting unauthorized productions), D'Oyly Carte defined itself as the organization that performed the operas exactly as their creators had intended ${ }^{5}$ Gilbert and Sullivan, both known as sticklers for detail, had shaped the original productions, and the performing traditions that the D'Oyly Carte Company maintained until its unhappy last days in the 1980s therefore went back in an unbroken line to the performances that Gilbert and Sullivan themselves had directed. Yet notwithstanding the efforts to maintain stability, the operas changed over the years ${ }^{6}$ The following paragraphs are intended to look at some of those changes and to raise some questions that those changes imply.

Until 1958, when Reginal Allen's First Night Gilbert $\mathcal{E}$ Sullivan appeared, Savoyards' interest in textual problems was lively but unfocused (Allen 1958) 7 Both performers and Gilbert \& Sullivan enthusiasts were aware that there were textual problems, that as the years and decades passed not everything that was being performed had been intended by the creators, but the ability to address these problems was hampered by the inaccessibility of sources. D'Oyly Carte jealously guarded the few full scores in its possession (productions were conducted from vocal scores) ${ }^{8}$ and the unauthorized published full scores in

5 On the origins of the D'Oyly Carte Opera Company and its establishment as the organization performing the operas in accordance with the creators' wishes, see Young 2003. Part B, pages 14-15, and Joseph 1994 pages 21-24.

Opera is a notoriously unstable genre, probably because so many interests figure in productions: there are composers, conductors, singers, instrumentalists, librettists, directors, choreographers, and scene designers - not to mention the producers who look after financial concerns. On the instability of operatic works, written by a scholar concerned with both texts and performance, see Gossett 2006

7 Allen was both an insider - he had secured the confidence of the D'Oyly Carte board, of which he became a member - and something of an outsider: an American collector, with bibliographic interests, and an awareness of the textual problems from which Gilbert's libretti suffered. His attempts to establish the text for the first night of each opera, although not always successful, constituted an important step in addressing the textual instability of the libretti, and the collection of libretti, vocal scores, and other material that he assembled and donated to what is now the Morgan Library and Museum (formerly the Pierpont Morgan Library) has proven an invaluable resource to subsequent editors. On the state of Gilbert \& Sullivan textual studies in the 1950s, see Allen's Prologue, pages xvii-xviii. Allen's efforts were confined to the libretti; with the exception of the vocal scores, the musical sources remained largely inaccessible and problematic.

$8 \quad$ Full scores give all the notes sung by all the singers (principals and chorus) and played by all the instrumentalists, while vocal scores give all the singers' parts but reduce the orchestral parts to the two staves of a piano score; vocal scores therefore provide much less information than full scores. On the problems posed by the Savoy Opera sources, see Broude 2008 
circulation had been scored up from unreliable band parts; the texts of libretti had been uncritically reproduced for trade editions from a variety of early sources. The publication of a critical edition of the operas (the first volume appeared in 1993) and of Ian Bradley's texts of the libretti, The Annotated Gilbert $\mathcal{E}$ Sullivan, were historicizing editions in the sense that they sought to present texts corresponding to specific states in which the edited works had existed, and that they were keen to explain to users the processes by which those texts had changed over time ${ }^{9}$ The implications of the sorts of changes discussed in the following paragraphs extend, of course, beyond the Savoy Operas; every performing genre, whether of drama, dance, or music, responds to forces that are unique to it, but there are also certain similarities in the ways all performing works are created, performed, transmitted, and experienced.

An important category of textual problems presented by the Savoy Operas requires the editor to distinguish between two sorts of adjustments made during first productions. On the one hand, there are compromises made to meet the sorts of unique exigencies that will arise in any production but that are unlikely ever to arise again. On the other hand, there are adjustments made for the larger purpose of improving the work. Princess Ida, Gilbert and Sullivan's eighth collaboration, which opened in 1884, provides a good example of a first-production-only problem.

Shortly before Princess Ida was to go into rehearsal, the tenor Henry Bracy was signed to sing the part of Prince Hilarion, the male romantic lead in the opera. It is a convention in this class of work that when the male romantic lead is a tenor, as he very often is, his is the highest male part in respect of range. This is the convention upon which Sullivan relied when he composed No. 20, the first to be composed of the three pieces in which Hilarion sings with his friends and confidants Cyril (another tenor) and Florian (a baritone) 10

Hilarion was Bracy's first role in a Savoy Opera, and it would be his last, for it soon became apparent that he did not have the high notes expected of a high tenor. Derward Lely, the Scottish tenor who sang Cyril, did have those high notes, and so, in the ensemble numbers for Hilarion, Cyril, and Florian that Sullivan composed after Bracy's shortcomings had become apparent - Nos. 12 and 13-Cyril (rather than Hilarion) was given the highest lines. But No. 20, the Finale to Act 2, which Sullivan had composed the previous summer, contained a dramatically important solo passage for Hilarion in which, at measure 95, Bracy was required to hit and hold a B-flat above middle $\mathrm{C}$, a note that a high

9 The first volume in the critical edition was Trial by Jury, edited by Steven Ledbetter (Gilbert and Sullivan 1993). The Annotated Gilbert and Sullivan, cited herein as Bradley 1996 first appeared in two volumes, the first issued in 1982 and the second in 1984; Bradley 1996 combines the contents of the earlier two volumes and provides new material.

References to act, number and measure are to Richard Sher's edition of Princess Ida, Gilbert \& Sullivan (2021), and to the original vocal score, Gilbert \& Sullivan 1883, first edition, second issue (first English issue), which agrees with Sher's edition with respect to act and number but which lacks measure numbers. On these events, see Gilbert and Sullivan 2021 
tenor should have been able to manage with ease. Sullivan, however, lacked confidence in Bracy's ability to sustain that note consistently, and so he rewrote Hilarion's line, lowering the B-flat by a full tone to A-flat, which he trusted Bracy to negotiate. The orchestral accompaniment was adjusted accordingly. The process of revision can be traced in Sullivan's holograph 11 Presumably, the A-Flat is what Bracy sang in the performances in which he participated.

However, in the piano vocal score of Princess Ida, which was prepared by George Lowell Tracy and engraved before the B-flat had been lowered to an A-flat, the B-flat remains, unaltered. And that B-Flat is what has been sung by Hilarions down to the present day. Now should an editor preparing a critical edition of Princess Ida print the B-flat or the A-flat?

Two approaches supported by familiar (though differing) theories suggest that it is the A-flat that an editor should print. If an editor adheres to the view that his or her edition should represent the composer's latest intentions, then it is the A-flat that clearly represents Sullivan's latest intentions. On the other hand, if an editor takes a social approach, then the A-flat represents the socialization of Sullivan's text, its accommodation to the realities of the institution for which and within which it was created. But this is really not a matter of latest intentions or socialized texts.

In deciding what to print in such a case, a conscientious editor will probably consider several factors. First is what may be called the narrative, i.e.: the sequence of events that has led to the change, including the creator's original intentions, the creator's revision, and the circumstances that led from the former to the latter. Then there is the evidence of the textual and of the performing traditions - two traditions that may not always be in agreement. Finally, there are the relative artistic merits of the original and revised states. In theory, this last is not a factor that should influence a critical editor, who should be concerned not with artistic quality but with what a text was - or was intended to be - at some specific moment in the past. But where the difference in quality seems significant, artistic merit can sometimes influence an editor's decision.

In the present case, the narrative is clear: Sullivan originally intended the B-flat, and changed it only because of a specific singer's limitations. As for the textual tradition, the B-flat was retained in the vocal score, even though it could have been changed (although the degree of Sullivan's involvement in the preparation of the vocal score is uncertain). The performing tradition is that of the B-flat. And, happily, Sullivan's original B-flat is musically superior to the altered line he contrived for Bracy. Richard Sher, the editor of the critical edition of Princess Ida (Sher 2021), prints the B-flat, and discusses the history of the readings in his critical apparatus.

But the case of Bracy and Hilarion is quite a simple one. The problem becomes more complicated when the effects of a change made to address the circumstances of a specific production are not just local or when a change seriously compromises the artistic quality of a work as a whole. H. M. S. Pinafore, produced

11 See Sullivan 1884 fol. $118^{\mathrm{r}}$, the tenth measure on the page. 
in 1878 , is an opera in which major structural changes made to accommodate a particular performer had unfortunate consequences.

In Pinafore, Sir Joseph Porter, the Admiralty's First Lord, has inappropriately fallen in love with the much younger - and socially inferior - Josephine, who is the daughter of a mere captain. Josephine has also fallen in love with someone socially beneath her: a sailor serving aboard the ship her father commands. In the end, when Josephine gets her sailor and all the principals are being paired off, Sir Joseph consents to marry his cousin Hebe. As the published texts stand, his seems a curiously arbitrary decision: Hebe has been a relatively minor character, who, unlike the other principals, has neither solo nor dialogue, and who participates in the Act 1 finale for no apparent dramatic reason.

The role of Cousin Hebe was written for a popular performer, Mrs. Howard Paul. As originally conceived, the part was a rounded, comic role: Cousin Hebe wants to marry Sir Joseph herself, she does everything she can to discourage Sir Joseph's infatuation, and she encourages Josephine to elope with the sailor whom Josephine loves (hence her presence onstage during the Act 1 finale, when plans for the elopement are being laid). The part as originally conceived is to be found in the licensing copy sent to the Lord Chamberlain three weeks before opening night (Gilbert 1878) 12

Shortly before opening night, however, Mrs. Howard Paul was dismissed, and it was necessary to find a replacement for her. The replacement whom Gilbert and Sullivan chose was Jessie Bond, one of the few performers in London able consistently to get her way with the famously irascible Gilbert. Bond was a singer, not an actress, and she agreed to take the role of Cousin Hebe on such short notice only on the condition that she would have no dialogue to speak; Gilbert accommodated her, and all of Hebe's dialogue was cut. In all the authorized published texts of Pinafore, Hebe has no dialogue, nor did Hebe ever have any speaking lines in any production of Pinafore mounted by the D'Oyly Carte Company. One other point: Pinafore was revived under Gilbert's direction in 1887, and had Gilbert wished, he could have restored Hebe's dialogue for the revival. The role was reprised by Jessie Bond, who by 1887 was in her tenth year with the D'Oyly Carte Company, and who by then had become thoroughly accustomed to roles requiring her to speak dialogue. But Gilbert did not restore the dialogue. He must certainly have understood that his original conception of Hebe, as intended for Mrs. Howard Paul, was sound and that in accommodating a temperamental and manipulative performer, he had weakened his libretto. There is no documentary or anecdotal evidence to suggest why the dialogue was not restored, but one reason, no doubt, was that the opera had been a hit without the suppressed dialogue, and Gilbert was not a librettist to tinker with something that had proven successful.

So we may ask: should an editor preparing a critical edition of Pinafore restore

12 On the dismissal of Mrs. Howard Paul and the adjustments made to accommodate Jessie Bond, see Young 2003. Part B, pages 14-15. These events are also recounted by Jessie Bond in Bond 1930 pages 58-61, though Bond's objectivity may be questioned. 
Hebe's dialogue? Suppressing Hebe's dialogue seriously compromises the internal consistency of the action, but both the textual and the performing traditions argue against restoration. Percy Young, the editor of the critical edition of Pinafore, opts not to restore the suppressed dialogue in the main body of his edition. He does, however, print all of the relevant passages in an appendix, so that productions using his edition can perform the suppressed dialogue and several have done so (Gilbert and Sullivan 2003. B:173-77). So here, as with Princess Ida, the editor has followed the textual and performing traditions, which are in agreement, and which were clearly in accordance with the creator's latest wishes. But in the case of Pinafore, the editor has done so believing that the altered version that he has printed is artistically inferior to what he might have printed.

The dilemma Young faced puts front and center the distinction touched upon above, that between work and performance (or production). According to traditional thinking, a work is a stable and continuing entity, whereas a performance or production is an instantiation of the work. Provided that the creator's conception be practical — provided that he or she asks no more than should be expected of any competent performer - it seems perverse to allow the problems that arise in a particular production to determine forever the shape of the work.

But there is no evidence that Gilbert or Sullivan ever made any distinction between production-specific adjustments and artistic improvements. They seem rarely to have thought any farther than the first run. They were, after all, practical men of the musical theatre, and they do not seem to have regarded their collaborations as immortal works of art. Even when, in 1885, they began reviving their earlier operas (The Sorcerer, first produced in 1874, was the first to be revived), they might change the scenery, but they very rarely modified the libretto or the music; they usually admitted changes to the published vocal scores and libretti only to correct errors in earlier states ${ }^{13}$ This attitude is no doubt typical of many dramatists and composers, who are creators confiding their creations to agencies often beyond their control - to actors, musicians, dancers, directors and producers - and for whom just having seen the piece through to opening night may seem a significant achievement.

Another sort of problem requiring editorial discretion occurs when the creator makes changes in response to censorship, whether explicitly imposed by an agent such as the licensing office of the Lord Chamberlain, or by critics, producers, or audiences, who exert a different but no less coercive force. Such

13 Thus, for example, new scenery was created for the revival of Pinafore in 1887. In this production the audience sat amidship, looking aft towards the quarterdeck. In the original production, the audience sat abeam, with the quarterdeck to the right and the mainmast to the left. The stage directions, however, were not completely revised to suit the new layout in the revival, an omission which has caused confusion.

One of Gilbert's best known efforts at inserting something topical in a revival occurred with a reference to the Boer War during a 1901 revival of Iolanthe; the line was considered inappropriate and likely to arouse strong political emotions, and Gilbert withdrew it. 
cases occur in Gilbert \& Sullivan's seventh collaboration, Iolanthe, which had its premiere on 25 November 1882, and which has more biting social and political commentary than any of the other Savoy Operas. Iolanthe deals satirically with the House of Peers, the British legal system, and the English preoccupation with birth, three seriously flawed institutions about which Victorian audiences were understandably sensitive. In this opera, a band of fairies, having been offended by a particularly arrogant peer, punishes the House of Lords by sending into Parliament a protégé, who, backed by the fairies' magical powers, implements legislation that will right certain social wrongs and will deny the Peers many of their ancient and cherished privileges.

Iolanthe had a difficult gestation; Gilbert's sketch-books show that his first ideas were much more inflammatory than the toned-down satire of the opera as we know it ${ }^{14}$ For Iolanthe, Gilbert's polishing process involved removing the elements with the sharpest edges. Notwithstanding his reputation as a martinet and his ability to keep performers in terror of him, Gilbert could be indecisive about his libretti, and the rewrites that were invariably required during rehearsals were often quite difficult for him. With Iolanthe, even more so than usual, Gilbert was juggling musical numbers and dialogue right up until opening night — and afterwards.

As constituted on opening night, Iolanthe's second act had two particularly bitter political pieces, the original No. 6, known as the "De Belville Song, or The Reward of Merit", and the original No. 9, a song beginning "Fold your flapping wings, soaring Legislature". The "De Belville Song" tells of a gentleman gifted as an artist, writer and inventor, and for whose accomplishments a peerage might have been a suitable reward. But no peerage was forthcoming until the gentleman inherited a safe seat in the House of Commons and began making "inconvenient speeches" there. At this point, a reward was quickly found: he was given a peerage and thereby banished to the House of Lords ${ }^{15}$

After opening night, Gilbert and Sullivan set about to tighten up the second act. There were two rounds of cuts separated by a few days; the alterations can be traced by comparing states of the first English edition of the libretto, the type for which was kept standing so that the text could be easily modified until the settled state was reached 16 The "De Belville Song" was cut during the first round of revisions. Unfortunately, although the lyric is preserved in

14 On the genesis of Iolanthe, see Perry 2005, and Perry et al. 2017. Part C, pages 2-15.

15 For the text of the "De Belville Song", see Gilbert and Sullivan 2017. Part C, pages 198-99. On the song's history, see Miller and Perry 2000

16 The London opening night is reflected by the first state of the British libretto (L1b in Gerald Hendrie's edition, Gilbert and Sullivan 2017), while the second is reflected in the second state of the British libretto (Hendrie's L1c). (The edition printed by J. M. Stoddart in Philadelphia and run off from plates made from stereos sent over from London, is the first published state of the libretto, designated by Hendrie L1a.) See the critical apparatus to Hendrie's edition of the libretto, Gilbert and Sullivan 2017. Part C, pages 19-62. References to act, number and measure or line are to this edition. 
the first two issues of the published libretto, all that survives of the music is a violin leader part, which provides just enough information to justify attempting a reconstruction but not enough to support a convincing one, and it is therefore impossible to assess the quality of music-cum-words ${ }^{17}$

"Fold your flapping wings" 18 was a victim of the second round of cuts, but fortunately both its words and music survive. This song contains some of the angriest passages in all the Savoy Operas. Sung by the fairies' reform-minded protegé, now an MP, the song deals uncomfortably with the question of London's underclasses and the system that perpetuates them. One verse reads:

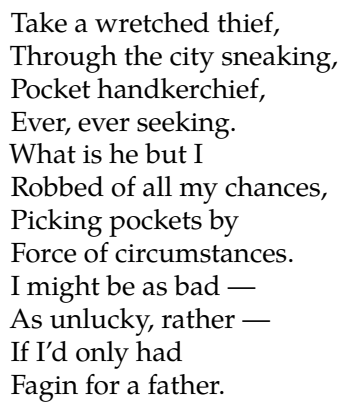

The number had been well received - indeed, it had been encored, and several critics had written very favorably of it. But other critics had objected that its subject was too serious for a comic opera ${ }^{19}$ In deciding to cut this number, Gilbert was no doubt responding to the need to compress the second act, but it is impossible not to believe that he also did so because he feared that retaining the number would frighten away some potential ticket buyers. Happily, however, Sullivan was reluctant to see the number cut, and, contrary to his usual practice of putting discarded numbers aside to be recycled when Gilbert presented him with a metrically suitable lyric, he kept the manuscript fascicle containing "Fold Your Flapping Wings" intact and had it bound into the end of his holograph

17 The number was sung in the New York production, but in the London production, Rutland Barrington, to whom the song had been assigned, was indisposed, and he recited rather than sang the number. A reconstruction has been attempted by Bruce Miller and Helga Perry; see Miller and Perry 2000

18 For an edition of the words and music, see Gilbert and Sullivan 2017. Part C, pages 181-90; for the words only, see Part C, pages 202-03.

19 The anonymous reviewer for The Sportsman praised the number, noting that it was "unanimously encored" (Anonymous 1882. 3). On the other hand, William BeattyKingston, writing for The Theatre, asserts that "it amazes and even startles one, like the fall of a red-hot thunderbolt from a smiling summer sky" (Beatty-Kingston 1883, 22).

20 See Sullivan 1882 in the manuscript's present state, it occupies Vol. 2, pages 161-174. 
both lyric and music, therefore, survive.

Should "Fold Your Flapping Wings" be restored in a critical edition of Iolanthe? Should a reconstruction of the "De Belville Song" be offered as part of the edition? Gerald Hendrie, who edited Iolanthe for the critical edition, does not restore "Fold Your Flapping Wings" - nor any of the other extant material cut either before or after opening night. But in appendices he does give the piece - both words and music - and as much of the other excised material — including the violin leader of the "De Belville" song - as survives. And both these decisions seem to me to be right: the declared aim of the Critical Edition is to establish a text that represents the settled state of each work, the state that Gilbert and Sullivan - perhaps misguidedly - allowed the opera to assume. It is not the business of the editor of an edition with this aim to second guess the creators of the work he is editing and to impose his own views, whether artistic or social, on the edited work. That way lies chaos.

Another sort of problem that confronts editors of performing works is how to manage changes that have been made, with or without the creators' approval, to replace material that was topical when a work was written but that has since become meaningless - or worse - offensive. Although an editor of a poem or novel would not think of making such changes, they are made in performing works with surprising frequency ${ }^{21}$ Several examples of such changes occur in The Mikado, Gilbert and Sullivan's ninth and most popular collaboration, produced in 1885 .

In the second act of The Mikado (lines 470-99), the Mikado, arriving with his royal entourage in the town of Titipu, inquires of the citizens as to the whereabouts of his runaway son, Nanki-Poo ${ }^{22}$ Informed that Nanki-Poo has "gone abroad", he asks for his son's address. The reply is "Knightsbridge". A year before The Mikado opened there had been a Japanese exhibition in the London neighborhood of Knightsbridge, and the reference would have been understood by The Mikado's first audiences. However, the meaning was lost when the exposition closed and its memory faded, and so it has become traditional for performers responding to the Mikado's query to substitute for "Knightsbridge" the name of some locale in or near the city in which their production is taking place (for example, for the annual production of a Gilbert \& Sullivan opera at Longwood Gardens outside Philadelphia, "Kennett Square", the town in which Longwood Gardens is located, might stand in for Knightsbridge). The editor of the critical edition of The Mikado (who is the author of this article) will print

21 With a performing work, there is a reciprocity between a text and its users the performers - that does not exist with a novel or a poem. The reader of a poem does not alter a passage that might be improved, but a performer not infrequently changes a note or an articulation, and conductors have been known to alter the scoring of orchestral works. One reason that this is so is that the reader of a novel is the novel's audience, while the reader of a performing text is a performer, mediating between text and audience, and the audience is one remove farther away from the text. Further on this matter, see Broude 2011. 24-33.

References to act and line numbers in The Mikado libretto are to Bradley 1996. 
"Knightsbridge", but will include a footnote explaining the practice of posting Nanki-Poo to locales more relevant to specific productions.

A slightly more complex problem occurs in Act 2, No. 7, in which Ko-Ko, Pitti-Sing, and Poo-Bah describe for the Mikado an execution that is supposed to have taken place. Pitti-Sing tells how, noticing her, the condemned man, who had previously been fearful, pulled himself together:

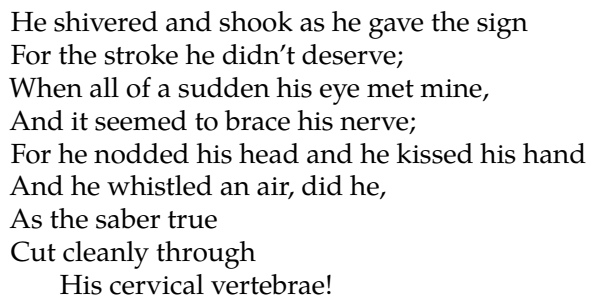

(lines 427-35)

At the words "he whistled an air", Sullivan inserted in the piccolo part, as a solo, a snatch from a popular song of the day, the "Cotillion Waltz". Presumably, whistling this air would convey to the audience the cavalier attitude of the man about to be beheaded. But the "Cotillion Waltz" soon dropped out of fashion, and since the meaning of inserting it had been to show that the condemned man whistled a well-known tune, it was pointless to retain the waltz. It has long been practice - exactly when the tradition began is not known - for the piccolo to play instead of the "Cotillion Waltz" the opening phrase of "The Girl I left Behind $\mathrm{Me}^{\prime \prime}$, a traditional military marching song dating back to the eighteenth century and familiar to most audiences as such. There is no authority for this except tradition: Sullivan's holograph (Sullivan 1885) has only the "Cotillion Waltz", uncancelled; the published vocal scores do not notice the piccolo insertion at all; and the surviving D'Oyly Carte band parts are too late to be reliable evidence of when this practice started. Yet substituting a traditional tune such as "The Girl I left Behind $\mathrm{Me}^{\prime \prime}$ for a song that has lost its significance makes good sense. For an editor producing a full score, the question is whether to follow the holograph or to draw on what is clearly a longstanding and sensible performing tradition. The critical edition of The Mikado will print the "Cotillion Waltz" on the piccolo line, but will also give "The Girl I Left Behind Me" as an ossia, printed on a cue-size staff above the piccolo line. A footnote will explain the situation.

More delicate is the problem of Gilbert's use of words acceptable in Victorian England but now regarded as offensive. In The Mikado, the n-word occurs twice. The first occurrence is in Act 1, No. 5a, in Koko's little list of people who might be executed without being missed: among them are "The [n-] serenader, and others of his race" (line 252). The second occurrence is in Act 2, No. 6, the 
Mikado's song about letting the punishment fit the crime:

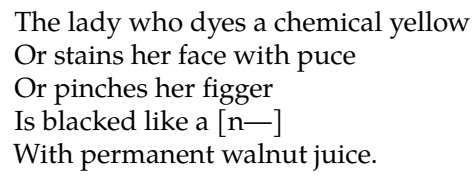

(lines 355-59)

On May 28, 1948, Rupert D'Oyly Carte, then director of the Company, wrote to The London Times:

We recently found that in America much objection was taken by coloured persons to a word used twice in the Mikado.... We consulted the witty writer on whose shoulders the lyrical mantle of Gilbert may be said to have fallen [A. P. Herbert]. He made several suggestions, one of which we adopted.

The first occurrence is now sung as "The banjo serenader, and others of his race". The retention of "others of his race" was no doubt motivated by the desire to tamper as little as possible with what Gilbert originally wrote, but not modifying the second half of the line leaves it clear that Gilbert's aversion is a racial matter. The Act 2 occurrence is remedied with these lines by Herbert:

\footnotetext{
The lady who dyes a chemical yellow

Or stains her face with puce

Or pinches her figger

Is painted with vigour

And permanent walnut juice.
}

In his communication to The Times, D'Oyly Carte blandly added that "Gilbert would certainly have approved" of Herbert's modifications. This is a highly questionable assumption. Gilbert shared many of the racial and ethnic prejudices of his Victorian contemporaries: the same mind that produced the witty lyrics for which Gilbert is celebrated also entertained many of the assumptions of racial superiority that helped the British to justify their Empire.

The question facing an editor of The Mikado is an instance of a larger one that is often raised: should works of the past be rewritten to suppress words or ideas considered offensive or politically incorrect today? Should racial and ethnic slurs be removed, should pronouns be made gender neutral, should history be re-written? The present writer believes that an editor of an historical edition has 
an obligation to history and that, distasteful as it may be, what Gilbert wrote must be retained. A compromise in this case is to print Gilbert's words in the text underlaid beneath the music in the full and vocal scores, but also to underlay, as ossia, Herbert's alternate versions 23

The last problem peculiar to performing works to be considered in this essay arises from performing traditions. Performing traditions are the unwritten traditions that a performing work acquires as it passes through time: they include interpretations of characters, readings of individual lines, and bits of business. As time goes by, a work's performing tradition often acquires components that are not authoritative but that audiences familiar with that tradition have come to regard as integral elements of that work ${ }^{24}$ Performing traditions are important because they transmit elements that text does not and/or cannot specify. Until the age of electronic recording, such traditions could be passed from performer to performer only by personal contact, with one performer's watching or being instructed by another ${ }^{25}$ Knowledgeable audience members are usually familiar with the performing traditions of works they know.

An interesting example of the problems presented by performing traditions occurs in a late Savoy Opera, The Yeomen of the Guard (1888), a work that hovers so uncertainly between comedy and tragedy that Gilbert and Sullivan were worried that the first-night audience would take their opera too seriously. In Yeomen, we meet Jack Point, a shallow jester who aspires to profundity. Point is in love with and engaged to his protégé, the young and pretty Elsie Maynard. Point, however, has an unattractive penchant for the main chance, and, in return for a small payment, he agrees to allow Elsie to marry Colonel Fairfax, a gallant officer who is shortly to be beheaded on trumped up charges and who wishes to take a wife in order to thwart the heirs who have contrived his death. When Fairfax escapes from custody, woos and wins Elsie, and then is reprieved, Point finds that he has lost Elsie. At the end of Yeomen, when the union of Fairfax and Elsie is celebrated, Gilbert's stage direction reads: "FAIRFAX embraces ELSIE as POINT falls insensible at their feet" (Act 2, 1.820) 26

The role of Point was created by George Grossmith, who played this final passage for laughs, twitching comically after he had fallen to the ground. This interpretation is consistent with Gilbert's text. Everything about Point points to his being a comic butt: he has aspirations well beyond his merits; he is far too old for Elsie; and his sense of values is distinctly deficient. In short, he should be

23 One cannot pretend that Gilbert did not write the offensive words or that he was unaware of how offensive they were or might become. No director today retains Gilbert's words, although the revisions proposed by Mr. Herbert - the first reflecting only slightly less prejudice than Gilbert's original - are not usually the preferred alternatives.

24 One of the most familiar examples of a performing tradition unsupported by textual evidence and no doubt contrary to the playwright's intentions is that of portraying Shylock as a sympathetic rather than a comic or devilish character.

25 Further on performing traditions - and how they sometimes find their way into texts - see Broude 2011 pages 33-40.

26 References to act and line number in Yeomen are to Bradley 1996 
a thoroughly unsympathetic character whose eventual discomfiture is reason for laughter. Moreover, since Grossmith created the part under Gilbert's direction, and since Gilbert controlled as many details as he could in the realization of his libretti, we must assume that Gilbert conceived Point's end as deserved and comic; had he not, he would never have allowed Grossmith to play the clown as the curtain falls.

However, when Yeomen went on tour and performers, freed from Gilbert's watchful eye, felt themselves at liberty to show initiative, two members of D'Oyly Carte touring companies - George Thorne and Henry Lytton - began to play Point for pathos. Instead of having Point writhe on the ground in comic frustration, their new interpretation had him die, presumably of a broken heart (in Lytton's case after having tenderly kissed the hem of Elsie's dress). This innovation adds depth to Point's character and is therefore more dramatically effective than a comic rendering: Point may be an intellectual fraud and an unprincipled rascal, but his love of Elsie is real, and his death results from the depth of his feeling.

At some point, Gilbert became aware of Thorne and Lytton's interpretation, but reports of his response to the innovation differ. Lytton asserts that Gilbert approved the new interpretation, and Rupert D'Oyly Carte, who succeeded to the directorship of the D'Oyly Carte Opera Company a year after Gilbert's death, confirms this. But neither of these accounts can be considered disinterested: Lytton wanted authorization for his interpretation, while D'Oyly Carte would have wanted to protect his company's reputation for preserving the performing traditions established by Gilbert and Sullivan themselves. A more objective witness is J. M. Gordon, stage manager for the 1897 revival of Yeomen, who reports that Gilbert refused to say whether Point dies or not: "The fate of Jack Point", Gilbert is supposed to have said, "is in the hands of the audience, who may please themselves whether he lives or dies" 27

What is clear is that Gilbert was committed to the stage direction as printed, for he never changed it, although he certainly could have done so in the several published forms of the libretto that postdated the innovation but preceded his death. Significantly, however, he did change several lines in the finale to alter Elsie's attitude towards Point from one of contempt to one of pity; the original lines describe Elsie as:

a merrymaid peerly proud,

Who loved a lord and who laughed aloud

At the moan of the merryman moping mum...

27 For Lytton's version, see Lytton 1922 174. For a review of responses to Lytton's interpretation, see Bailey 1952. 319-22. Gordon's report remains in manuscript but is quoted in Bradley|1996 514. 
The revised text describes her as:

a merrymaid nestling near,

Who loved a lord — but who dropped a tear

At the moan of the merryman moping mum...

$(11.811-12)$

Gilbert evidently wished to retain the ambiguity of "Point falls insensible", allowing actors the option to interpret the character either way, but he was sensitive enough to the advantages of the pathetic interpretation to revise Elsie's lines. To this day, this passage is played for pathos. Should an editor of Yeomen print the earlier or the later version of Elsie's song? Should the final stage direction be emended to something like "POINT dies" or "FAIRFAX embraces ELSIE as POINT expires at their feet?" After all, if Point is to die, something more explicit than "falls insensible" is required: there is a substantial difference between insensibility (he may recover and go on to pursue his career with another protégé) and dying.

In The Complete Annotated Gilbert and Sullivan, Bradley prints the revised lines but preserves Gilbert's original stage direction. Bradley's text therefore represents not the settled state of Yeomen - the opera was settled before the touring companies were formed and sent on the road - but a revised state. But Bradley's edition is not committed to representing the settled state; quite the contrary, for all the historical background that Bradley provides, his edition follows a longstanding tradition in the publication of dramatic texts: that the edition reflect what is currently being played rather than what was originally written 28 In his notes, Bradley gives the original lines and recounts the circumstances behind the change in those lines and in the interpretation of the stage direction. But no decision that an editor could make in this crux would be neutral: Bradley's decision to print the revised lines rather than the original points towards the pathetic ending; printing the original would favor the comic but would not rule out the pathetic. After all, Thorne and Lytton introduced the pathetic tradition while the original lines were still being sung.

So far we have been talking about creators and editors and editions. An editor of a critical edition of a Savoy Opera makes a sound decision when he or she decides to produce a text that represents the settled state of that opera during its first production. But performers and directors who use that text today are another matter altogether: the job of the editor of a critical edition is to present a text representing (insofar as evidence permits) what existed - or would have existed, had every mechanical slip been caught in proof - at some specific

28 For Bradley's statement of his policy, see Bradley 1996. xii. On this practice, which applies both to opera libretti and to play quartos representing plays "as recently acted by [... ]", see Broude 2011. 34-40. 
moment in the past, but the job of a producer or director is to make the work effective in the present, and what may have made an effective production at one time and place may not excite an audience in other circumstances. The circumstances under which any revival is mounted are always different from the circumstances of a first production. This is especially the case when a work considered a "classic" is revived: the work is revived because it has already demonstrated that it has audience appeal, and much of the audience may already be familiar with the work. The case is particularly acute with the Savoy Operas, which have a fan base much of which is knowledgeable about minute details. Every good director will take these facts into account.

Gilbert cut Hebe's dialogue to accommodate Jessie Bond; he cut "Fold Your Flapping Wings" because he wanted to quicken the pace of the second act, and if something had to go, then that something might as well have been a number that might offend some of his audience and thereby reduce ticket sales. But 2021 is not 1878 or 1882 . Jessie Bond no longer plays Hebe, and the idea that poverty breeds crime is neither new nor shocking. Nor is pacing an issue with a repertory work like Iolanthe, which many members of the audience will know by heart. If anything, today's audience at a Savoy Opera wants more Gilbert and Sullivan rather than less, and if a director can offer something that is new but that is also in some way authentic, then so much the better. A director who wants to give his production something novel but authentic could ask for nothing better than to restore Hebe's dialogue or "Fold Your Flapping Wings".

Operas that are fortunate enough to enjoy extended lives come to exist in multiple states. (And this is as true for performing works of all sorts as it is for the Savoy Operas.) A single text of an opera - which is what the text of a critical edition must be - can represent only one state. People involved with performing works - actors, singers, conductors, directors and producers - all claim considerable freedom in realizing texts, and few good performers will regard any text - the composer's, the librettist's, or the editor's - as altogether binding. An edition of a performing work is not an end in itself but a means to performance, and so regardless of what state of a work an editor decides his or her text should represent, it should be understood that editorial responsibilities include providing, by means of critical apparatus, footnotes and appendices, enough information about the textual and performing traditions of the work to enable those who perform it to exercise intelligently the freedom they will almost certainly claim.

\section{Bibliography}

Allen, Reginald, 1958. "Prologue." In The First Night Gilbert E Sullivan, edited by Reginald Allen, New York (NY): The Limited Editions Club \& The Heritage Club, pages xi-xxi.

AnONYmous, November 1882. "Review of Iolanthe." The Sportsman page 3. 
Bailey, Leslie, 1952. The Gilbert and Sullivan Book. London: Cassel.

Beatty-Kingston, William, January 1883. "Review of Iolanthe." The Theatre pages 21-22.

Bond, Jessie, 1930. The Life and Reminiscences of Jessie Bond, the Old Savoyard as Told by Herself to Ethel Macgeorge. London: John Lane.

Bradley, IAN, 1996. The Complete Annotated Gilbert \& Sullivan. Oxford: Oxford University Press. [This is a revised, single-volume edition of the two volumes first published as The Annotated Gilbert $\mathcal{E}$ Sullivan. London \& New York (NY): Penguin Books. 1982-84].

Broude, Ronald, 2008. "The Gilbert \& Sullivan Critical Edition and the Full Scores that Never Were." Textual Cultures 3(2), pages 71-89.

- 2011. "Performance and the Socialized Text." Textual Cultures 6(2), pages $23-47$.

Gaskell, Philip, 1978. From Writer to Reader: Studies in Editorial Method. Oxford: Clarendon Press.

Gilbert, William Schwenck, 1878. “[H. M. S. Pinafore licensing copy.].”

Gilbert, William Schwenck and Arthur Sullivan, 1884. Princess Ida, or Castle Adamant. London: Chappell \& Co., Ltd. [First British edition of the vocal score.].

- 1993. Trial by Jury, Gilbert $\mathcal{E}$ Sullivan: The Operas, volume 1, edited by Steven Ledbetter. New York (NY) \& Williamstown: Broude Brothers.

- 2003. H. M. S. Pinafore, Gilbert E Sullivan: The Operas, volume 3, edited by Percy Young. New York (NY) \& Williamstown: Broude Brothers.

- 2017. Iolanthe, Gilbert $\mathcal{E}$ Sullivan: The Operas, volume 6, edited by Gerald Hendrie. New York (NY) \& Williamstown: The Broude Trust.

- 2021. Princess Ida, Gilbert \& Sullivan: The Operas, volume 7, edited by Richard Sher. New York (NY) \& Williamstown: The Broude Trust. [forthcoming].

Gossett, Philip, 2006. Divas and Scholars: Performing Italian Opera. Chicago (IL) \& London: University of Chicago Press.

Joseph, Tony, 1994. The D'Oyly Carte Opera Company 1875-1982. Bristol: Bunthorne Books.

Lytton, Henry, 1922. The Secrets of a Savoyard. London: Jarrolds. 
MACKIE, DAvid, 2018. Nothing Like Work. Tolworth, Surrey: Grosvenor House.

Miller, Bruce and Helga Perry, 2000. "The Reward of Merit? An Examination of the Suppressed 'De Belville' Song in Gilbert and Sullivan's Iolanthe." Sir Arthur Sullivan Society Magazine 51, Supplement [Autumn], pages 1-17.

Perry, Helga, 2005. Everything that's Excellent. Master's thesis, University of Birmingham, Barbour Institute.

Perry, Helga, Gerald Hendrie, and Dinah Barsham, 2017. "Introduction." In Iolanthe, authored by Gilbert, William Schwenck and Sullivan, Arthur, Gilbert $\mathcal{E}$ Sullivan: The Operas, volume 6, edited by Gerald Hendrie, New York (NY) \& Williamstown: The Broude Trust, pages 1-17.

Rees, Terrence, 1964. Thespis, A Gilbert and Sullivan Enigma. London: Dillon.

Rollins, Cyril and R. John WitTs, 1962. The Gilbert and Sullivan Operas: A Record of Productions 1875-1961. Several supplements were issued to bring coverage through 1982; these were issued informally.

Sher, Richard, 2021. "Critical Apparatus." In Princess Ida, authored by Gilbert, William Schwenck and Sullivan, Arthur, Gilbert $\mathcal{E}$ Sullivan: The Operas, volume 7, edited by Richard Sher, New York \& Williamstown: The Broude Trust, page n.p. [forthcoming].

Sullivan, Arthur, 1882. "Iolanthe." [Autograph manuscript.].

— 1884. "Princess Ida." [Autograph manuscript.].

— , 1885. "The Mikado." [Autograph manuscript.] A facsimile of this manuscript has been published as The Mikado. Operetta in Two Acts with Libretto by W. S. Gilbert. London: Gregg International Publishers Limited, 1968.

Young, Percy, 2003. “Introduction." In H. M. S. Pinafore, authored by Gilbert, William Schwenck and Sullivan, Arthur, Gilbert $\mathcal{E}$ Sullivan: The Operas, volume 3, edited by Percy Young, New York (NY) \& Williamstown: Broude Brothers, pages 3-30. 